\title{
Effect of Schoolbag Weight on Musculoskeletal Pain among Primary School Children in Yaounde, Cameroon: A Cross- sectional Study
}

Wiliam Richard Guessogo, ${ }^{1}$ Peguy Brice Assomo-Ndemba, ${ }^{2}$ Edmond Ebal-Minye, ${ }^{1}$ Jerson Mekoulou-Ndongo, ${ }^{3}$ Claude Bryan Bika-Lélé, ${ }^{3}$ William MbangBian, ${ }^{1}$ Eva Linda Djuine-Soh, ${ }^{1}$ Jean Bertrand Ondoa, ${ }^{1}$ Samuel Honoré Mandengue, ${ }^{3}$ Abdou Temfemo. ${ }^{4}$

\begin{abstract}
Background: Heavy schoolbags are known to cause health problems for school children. The aim of this study was to determine the effects of carrying heavy schoolbags on the musculoskeletal pain among primary school children of the two subsystems in Yaounde, Cameroon. Methods: A cross-sectional study was carried out in primary schools in Yaounde. A total of $457 \mathrm{school}$ children (8.2 \pm 2.2 years) were included, 202 from the French-speaking subsystem, and 255 from the English-speaking subsystem. Parameters studied included weight, height, and schoolbag weight. A questionnaire was used to collect socio-demographic information and potential musculoskeletal pain in three regions: back, shoulders, and neck. Results: The mean weight of children and their bags was $28.4 \pm 8.2 \mathrm{~kg}$ and $5.2 \pm 2.3 \mathrm{~kg}$ respectively. More than $50 \%$ of school children in the two subsystems carried a schoolbag weighing more than $15 \%$ of body weight. The back (38\%) was the least affected area in comparison to the shoulders ( $58.6 \%)$ and neck ( $42.4 \%)$ (p<0.001). Carrying heavy bags and walking to school was associated with pain in the back, shoulders, and neck. School children in the French-speaking subsystem had lower risk (adjusted odds ratio $0.438,95 \%$ confidence interval $=0.295-0.651 ; \mathrm{p}<0.001$ ) to develop a sore neck compared to peers from the English-speaking subsystem. Conclusion: Carrying heavy schoolbags is associated with musculoskeletal pain in schoolchildren. The means moving to and from school is a main risk factor of developing musculoskeletal pain. French-speaking school children develop less neck pain than English-speaking school children.
\end{abstract}

Key Words: Weight-Bearing; Musculoskeletal Pain; Primary School; Cameroon (Source: MeSH-NLM).

\section{Introduction}

Excessive schoolbag weight is a health problem commonly reported in the pediatric age group.' Carrying heavy schoolbags is associated with a multitude of body biomechanical afflictions or disorders such as changes in the sagittal plane in posture and balance, spinal curvature, consistency of repositioning and musculoskeletal discomfort. ${ }^{2-7}$ The particular situation of musculoskeletal pain is the basis of studies investigating the relative weight limit of schoolbags which has less impact on the imbalance of physiological and biomechanical functions..$^{2-7,8}$

Previous studies showed that schoolbags should be within acceptable limits of $10-15 \%$ of a child's body weight to avoid musculoskeletal pain. ${ }^{1,8-14}$ Secondary school children are a target group at risk for musculoskeletal pain because of the maximum development of the appendicular skeletal system that occurs especially during puberty. ${ }^{15,16}$ Other studies conducted in the population of primary school pupils revealed negative effects on the musculoskeletal system associated to heavy schoolbag carriage. $6,17-22$ In addition, considering the musculoskeletal development of school-age in children, the schoolbag weight and the negative consequences of heavy loads can lead to problems in the development of the spine. ${ }^{23-26}$ Studies reported that the development of back pain in children can increase the risk of developing chronic back pains in adulthood. ${ }^{27,28}$
Items contributing to the weight of schoolbags include school manuals, and additional items such as afternoon tea, bottles of water, sports equipment, and jackets. ${ }^{29}$

Unfortunately, despite the negative consequences of carrying heavy schoolbags on the children's health, ${ }^{2-7}$ to our opinion, this situation does not seem to worry parents and school officials. It is still accepted today that the weight of the backpack should be further reduced in order to limit the prevalence of back pains in children; ${ }^{30}$ and with this regard many studies have been conducted in a variety of educational systems. $1,2,6,8,9,18,20,21,29,31-33$

In Cameroon, the educational system is bilingual, and is subdivided into two sub-systems: French-speaking and English-speaking. In November 2017, the Government recommended and prescribed one schoolbook per subject matter instead of the multiple books per subject as it was previously. Before this Government decision, the mean number of textbooks per student was 13 in Cameroon, whereas the average in Africa was 8.5.34 One of the objectives of this prescription was to prevent health risks associated with increasing volume and weight of schoolbag.

Since this Government decision, no scientific investigation in our knowledge has been carried to evaluate the current impact of the weight of the schoolbag on musculoskeletal pain in Cameroon.

\footnotetext{
1 National Institute of Youth and Sports, Yaoundé, Cameroon.

${ }_{2}$ Faculty of Medicine and Biomedical Sciences, University of Yaounde 1, Yaounde, Cameroon.

${ }_{3}$ Exercise and Sport Physiology and Medicine Unit, Faculty of Science, University of Douala, Cameroon.

Degrees: ${ }^{1} \cdot \mathrm{PhD} ;{ }^{2} \cdot \mathrm{MD}, \mathrm{PhD} ;$

${ }^{3} . \mathrm{PhD} ;{ }^{4} \cdot \mathrm{PhD} ;{ }^{5} . \mathrm{PhD} ;{ }^{6} . \mathrm{MSc}$

$\mathrm{MSc} ;{ }^{8} . \mathrm{MSc} ;{ }^{9} . \mathrm{PhD} ;{ }^{10} . \mathrm{PhD}$
}

${ }_{4}$ Faculty of Medicine and Pharmaceutical Sciences, University of Douala, Cameroon. 
The purpose of this study was to determine the effects of carrying a heavy schoolbag on the musculoskeletal pain among primary school children in the English-speaking and French-speaking educational systems of Cameroon.

\section{Methods \\ Study design}

A cross-sectional study was conducted in primary schools of the two subsystems in Yaounde, the Capital of Cameroon, during the first term $2017 / 2018$ school year.

\section{Sampling}

In Cameroon, the two sub-systems (French-speaking and Englishspeaking) operate independently, particularly on the aspect of training programs, with specific books and schedules used in each sub-system. According to the authorization of the Regional Delegate of the Ministry of Basic Education, we used a non-probability sampling method of convenience to investigate. In each school, one class per level of study (6 levels) was chosen. In order to avoid any interference, the administration of each school randomly selected one class per level in the three classes that comprises each level, using the draw method from the list of classes. The school administration was not informed of the purpose of the study. All school children of both sexes attending the day of collection, able to walk and wear their schoolbag independently were included in the study. According to their medical information available in the administration, school children who were diagnosed by a medical doctor as having spinal and musculoskeletal problems such as leg length discrepancies were excluded.

\section{Data collection}

The body weight and schoolbag weight were measured using the same Tanita BC 532 electronic scale (Tokyo, Japan) placed on a flat and hard surface, calibrated before the start of data collection. The weight of each participant was first measured without schoolbag, then after, carrying his schoolbag, to obtain the total weight. The difference of the two weights was recorded as the schoolbag weight, and then, the schoolbag weight percentage compared to body weight was determined. The height was measured using a Graduated scale Mark Seca (Hamburg, Germany).

A questionnaire developed for the study and deriving from the Standardized Nordic Body Map Questionnaire was used to collect additional information. The questionnaire was administered and each student answered, if necessary, with the help of the investigator. This study tool consisted of a self-administered questionnaire translated in French and in English, the two official languages spoken in Cameroon. The tool was pre-tested in order to simplify the language of the questions. A diagram was introduced to indicate the body parts to report the pain. The questionnaire included: the mean of moving to and from school and the location of musculoskeletal pain.

\section{Data analysis}

Data were entered into an Excel spreadsheet (Microsoft Office 2016) before being exported to the statistical analysis software StatView 5.0 for windows (SAS Institute, Inc., IL, USA). Categorical variables were presented as frequency and percentage while continuous variables were presented as mean \pm standard deviation (SD). The schoolbag weight as percentage of body weight (\%BW) was classified into those with $\leq 10 \%$ BW, those with BW located from $>10 \%$ to $\leq 15 \%$, and those with $>15 \%$ BW. The descriptive statistics were used to determine the anthropometric characteristics of the participants, the number of school children in each category of schoolbag weight as percentage of body weight, and the prevalence of pain symptoms in different regions of the body. The unpaired Student t-test was used to compare the mean schoolbag weight among school children in the two educational subsystems as well as the characteristics of the participants.
A Pearson chi square test $\left(x_{2}\right)$ was used to compare percentages of participants in different categories of schoolbag weight to body weight. Multivariate logistic regression was used to identify factors associated with the presence/absence of pain on different body regions (back, shoulders and neck). The outcome variable was the presence of pain on the body region of interest and the independent variables (factors) included gender, age, educational system, means of transport and $\% B W$. Adjusted values of odd ratio (aOR) along with their confidence interval at $95 \%(95 \% \mathrm{Cl})$ and level of significance were computed. A logtransformed value of likelihood was used to appraise the goodness-offit of each logistic regression model. Statistical significance was set at p-value $<0.05$

\section{Ethics Clearance}

The current study received the approval of the National Committee of Ethics for Scientific Research and was conducted in conformity with the recommendations of the Declaration of Helsinki revised in 1989. Access into schools was authorized by the Regional Delegate of the Ministry of Basic Education. An informed written consent form including the description of the study and its importance was distributed to school children to obtain parental consent.

\section{Results}

\section{Characteristics of participants}

A total of 457 school children (50.6\% boys) were included; 202 (44.2\%) from the French-speaking subsystem and 255 (55.8\%) from the Englishspeaking subsystem. The mean age, body height, body weight and body max index (BMI) of participants were $8.2( \pm 2.2)$ years, $132.3( \pm 14.4) \mathrm{cm}$, $28.4( \pm 8.2) \mathrm{kg}$ and $16.1( \pm 2.9) \mathrm{kg} / \mathrm{m}^{2}$ respectively.

No difference was found in the characteristics between boys and girls in both educational subsystems (Table 1).

Table 1. Sociodemographic and anthropometric characteristics of participants

\begin{tabular}{lcccccc}
\hline $\begin{array}{l}\text { Educational } \\
\text { System }\end{array}$ & Gender & $\mathbf{n}$ & $\begin{array}{c}\text { Age } \\
(\mathrm{yrs})\end{array}$ & $\begin{array}{c}\text { Height } \\
(\mathrm{cm})\end{array}$ & $\begin{array}{c}\text { Weight } \\
(\mathrm{kg})\end{array}$ & $\begin{array}{c}\mathrm{BMI} \\
\left(\mathrm{kg} / \mathrm{m}^{2}\right)\end{array}$ \\
\hline $\begin{array}{l}\text { French- } \\
\text { speaking }\end{array}$ & Boys & 100 & $8.1 \pm 2.3$ & $132.4 \pm 16.4$ & $30.2 \pm 9.9$ & $17.1 \pm 3.9$ \\
& Girls & 102 & $7.8 \pm 2.3^{\mathrm{NS}}$ & $131.0 \pm 15.6^{\mathrm{NS}}$ & $28.4 \pm 8.8^{\mathrm{NS}}$ & $16.3 \pm 3.3^{\mathrm{NS}}$ \\
\hline $\begin{array}{l}\text { English- } \\
\text { speaking }\end{array}$ & Boys & 129 & $8.6 \pm 2.0$ & $133.3 \pm 12.8$ & $28.2 \pm 6.7$ & $15.9 \pm 1.7$ \\
& Girls & 126 & $8.3 \pm 2.1^{\mathrm{NS}}$ & $132.2 \pm 13.3^{\mathrm{NS}}$ & $27.3 \pm 7.6^{\mathrm{NS}}$ & $15.4 \pm 2.2^{\mathrm{NS}}$ \\
\hline Total & & 457 & $8.2 \pm 2.2$ & $132.3 \pm 14.4$ & $28.4 \pm 8.2$ & $16.1 \pm 2.9$ \\
& & & & & & \\
\hline
\end{tabular}

Legend: $\mathrm{BMI}=$ Body mass index; Educ. Syst. = Educational system. ${ }^{\mathrm{NS}}=$ Non significant difference between boys and girls.

\section{Schoolbag weight to body weight}

The mean schoolbag weight in the whole sample was $5.2( \pm 2.3) \mathrm{kg}$ ranging from $1.2 \mathrm{~kg}$ to $14.8 \mathrm{~kg}$ with no significant difference in the French-speaking subsystem $(5.6 \pm 2.2 \mathrm{~kg}$, ranging from $1.2 \mathrm{~kg}$ to 11.0 $\mathrm{kg})$ compared to the English-speaking subsystem $(5.1 \pm 2.4 \mathrm{~kg}$, ranging from $1.6 \mathrm{~kg}$ to $14.8 \mathrm{~kg})$. The majority of students $(62.30 \%)$ belonged to the category $>15 \%$, both in the French-speaking (67.32\%) and Englishspeaking subsystems $(58.43 \%$ ) (Table 2 ).

\section{Musculoskeletal pain}

A total of $174(38.1 \%)$ participants reported pain at their back and 194 $(42.4 \%)$ at the neck. But, $58.6 \%$ of them reported having pain at the shoulders. The prevalence of pains was significantly different in the back $(p=0.0091)$ and the neck $(p=0.0284)$ in the different category percentages of body weight. Self-reported pains at the back, shoulders and neck across schoolbag weight related to body weight are detailed in Table 3. 


\section{Risk factors}

In relation to risk factors, children whose schoolbag weight was $>15 \%$ of their body weight were almost 4 times more likely to develop neck pain compared to those whose schoolbag weight was $<10 \%$ of their body weight $(\mathrm{aOR}=3.56,95 \% \mathrm{Cl}=1.38-9.21, \mathrm{p}=0.008)($ Table 4$)$.

Except from the mean of moving to and from school, the other variables (gender, age, educational system) were not significantly associated, with the risk of developing localized pain at the back, shoulders and neck. Children who moved using public car transport to school were less likely to develop musculoskeletal disorders at their back $(\mathrm{aOR}=$ $0.40,95 \% \mathrm{Cl}: 0.27-0.60, \mathrm{p}<0.001)$, shoulders $(\mathrm{aOR}=0.48,95 \% \mathrm{Cl}=0.32-$ $0.72, \mathrm{p}=0.0004)$ and neck $(\mathrm{aOR}=0.56,95 \% \mathrm{Cl}=0.37-0.83, \mathrm{p}=0.0043)$ compared to those walking to school. Moreover, school children who were enrolled in the French-speaking subsystem were less likely (aOR $=0.44,95 \% \mathrm{Cl}=0.30-0.66, \mathrm{p}<0.001)$ to develop a sore neck compared to those in the English-speaking subsystem (Table 4).
Table 2. Distribution of school children by schoolbag weight as percentage of body weight

\begin{tabular}{|c|c|c|c|c|}
\hline \multirow[b]{2}{*}{ Characteristic } & \multirow[b]{2}{*}{ Total $(n=457)$} & \multicolumn{2}{|c|}{ Educational system } & \multirow[b]{2}{*}{$p$-value } \\
\hline & & $\begin{array}{l}\text { English- } \\
\text { speaking } \\
(n=255)\end{array}$ & $\begin{array}{l}\text { French- } \\
\text { speaking } \\
(n=202)\end{array}$ & \\
\hline \multirow[t]{2}{*}{ SBW (kg) } & Mean ( $($ SD) & Mean $( \pm S D)$ & Mean $( \pm S D)$ & \\
\hline & $5.2( \pm 2.3)$ & $5.1( \pm 2.4)$ & $5.6( \pm 2.2)$ & 0.0282 \\
\hline \%BW & $\mathrm{n}(\%)$ & $\mathrm{n}(\%)$ & $\mathrm{n}(\%)$ & \\
\hline$\leq 10 \%$ & $29(6.4)$ & $17(6.66)$ & $12(5.94)$ & 0.8875 \\
\hline$>10 \%$ to $\leq 15 \%$ & $143(31.3)$ & $89(34.90)$ & $54(26.73)$ & 0.0769 \\
\hline$>15 \%$ & $285(62.3)$ & $149(58.43)$ & $136(67.32)$ & 0.064 \\
\hline
\end{tabular}

Legend: SBW $=$ Schoolbag weight.

Table 3. Prevalence of pain symptoms in different regions of the body

\begin{tabular}{|c|c|c|c|c|c|c|}
\hline \multirow[b]{2}{*}{ Regions and symptoms } & \multirow[b]{2}{*}{ Total } & \multicolumn{3}{|c|}{ Schoolbag weight (kg) } & \multirow[b]{2}{*}{$x^{2}$} & \multirow[b]{2}{*}{$p$-value } \\
\hline & & $\begin{array}{l}\leq 10 \% \\
\mathrm{n}(\%)\end{array}$ & $\begin{array}{c}>10 \% \text { to } \leq 15 \% \\
\text { n (\%) }\end{array}$ & $\begin{array}{l}>15 \% \\
n(\%)\end{array}$ & & \\
\hline \multicolumn{7}{|l|}{ Back } \\
\hline NO & $283(61.9)$ & $18(62.1)$ & 105 (71.9) & $160(56.7)$ & 9.40 & 0.0091 \\
\hline YES & $174(38.1)$ & $11(37.9)$ & $41(28.1)$ & $122(43.3)$ & & \\
\hline \multicolumn{7}{|l|}{ Shoulders } \\
\hline NO & $189(41.4)$ & $14(48.3)$ & $66(45.2)$ & $109(38.7)$ & 2.31 & 0.3144 \\
\hline YES & $268(58.6)$ & $15(51.7)$ & $80(54.8)$ & $173(61.3)$ & & \\
\hline \multicolumn{7}{|l|}{ Neck } \\
\hline NO & $263(57.6)$ & $23(79.3)$ & $87(59.6)$ & $153(54.3)$ & 7.12 & 0.0284 \\
\hline YES & $194(42.4)$ & $06(20.7)$ & $59(40.4)$ & $129(45.7)$ & & \\
\hline
\end{tabular}

Table 4. Risk factors for musculoskeletal symptoms in the back, neck and shoulders.

\begin{tabular}{|c|c|c|c|c|c|c|}
\hline \multirow{2}{*}{ Variables } & \multicolumn{2}{|l|}{ Back } & \multicolumn{2}{|c|}{ Shoulders } & \multicolumn{2}{|c|}{ Neck } \\
\hline & aOR $(95 \% \mathrm{Cl})$ & P-value & aOR $(95 \% \mathrm{Cl})$ & P-value & aOR $(95 \% \mathrm{Cl})$ & p-value \\
\hline \multicolumn{7}{|l|}{ Gender } \\
\hline Girls & 1 & & 1 & & 1 & \\
\hline Boys & $1.02(0.69-1.51)$ & 0.927 & $1.19(0.81-1.74)$ & 0.381 & $1.35(0.92-2.00)$ & 0.128 \\
\hline Age (years) & $1.05(0.95-1.15)$ & 0.334 & $0.97(0.89-1.07)$ & 0.574 & $1,05(0.96-1.15)$ & 0.295 \\
\hline \multicolumn{7}{|l|}{ \% Body Weight } \\
\hline$\leq 10$ & 1 & & 1 & & 1 & \\
\hline$>10$ to $\leq 15$ & $0.58(0.24-1.37)$ & 0.212 & $1.12(0.49-2.53)$ & 0.788 & $2.62(0.98-6.95)$ & 0.053 \\
\hline$>15$ & $1.19(0.53-2.70)$ & 0.670 & $1.48(0.67-3.25)$ & 0.327 & $3.56(1.38-9.21)$ & 0.008 \\
\hline \multicolumn{7}{|l|}{ Educational System } \\
\hline English -speaking & 1 & & 1 & & 1 & \\
\hline French-speaking & $1.24(0.83-1.84)$ & 0.301 & $1.52(1.03-2.25)$ & 0.003 & $0.44(0.30-0.66)$ & $<0.001$ \\
\hline \multicolumn{7}{|l|}{ Mean of transportation } \\
\hline Feet & 1 & & 1 & & 1 & \\
\hline Public car transport & $0.40(0.27-0.60)$ & $<0.001$ & $0.48(0.32-0.72)$ & 0.0004 & $0.56(0.37-0.83)$ & 0.0043 \\
\hline
\end{tabular}

Legend: $\mathrm{aOR}=$ adjusted Odds Ratio; $\mathrm{Cl}=$ Confidence Interval 


\section{Discussion}

The objective of the current study was to investigate the association between schoolbag weight and musculoskeletal pain among Cameroonian school children.

We found that the average percentage of the schoolbag weight relative to the body weight of the school children was well above the recommended limits $(10-15 \%)^{12}$ in the two Cameroonian educational sub-systems. In addition, musculoskeletal pain was common in school children sample with a high prevalence of back pain compared to the neck pain and shoulders pain. Our study showed that the average of schoolbag weight in the whole population is close to what is reported by other authors.9,27,35 Nevertheless, this value is higher than those found by Mwaka et al. ${ }^{1}$, Dianat et al. ${ }^{19}$, and Furjuoh et al. ${ }^{36}$ On the other hand, the value obtained in school children in the present study is lower than that reported by Ibrahim ${ }^{31}$ and Dorji et al. ${ }^{37}$ This disparity in schoolbag weight in these different studies could be explained by differences in curricula in each country, by levels of development, and by behavioral and cultural differences between countries.

A possible reason for this increase in the average of schoolbag weight found in our study compared to the norms would be the particular context of the textbook policy in Cameroon. Indeed, the Government published in November 2017 a text fixing for each subject matter one textbook, but, to our observation of the educational environment, there is persistent violation and non-respect of this regulation, leading to an increase the weight of the schoolbag.

The percentage of the weight of the schoolbag relative to the body weight of school children was higher in the French-speaking subsystem compared to the English-speaking subsystem. Usman et al. ${ }^{38}$ reported a slightly higher value among school children in Karachi, Pakistan. On the other hand, the percentage obtained in our study is higher than those obtained by some authors. ${ }^{1,9,18,35}$ Some authors noted percentages close to the recommended standard, like Al-Hazzaa ${ }^{33}$ and Grimmer et al.39

The results of our study revealed a higher proportion of school children $(67.3 \%)$ in the category $>15 \%$ of body weight in the French-speaking subsystem. This observation justifies the fact that for a decade in Cameroon, there was a gradual loss of interest in the French-speaking subsystem in favor of the English-speaking subsystem. Indeed, the English-speaking subsystem is characterized with an earlier specialization of the studies, and leads to a reduction of the number of textbooks. This result is consistent with the one generally observed in many studies, ${ }^{17,19,36}$ thus explaining the difference in educational systems and curricula. This result may also account for the low proportion of musculoskeletal symptoms in the participants of our study compared to some similar studies where the percentages was generally high i.e. more than $60 \% .^{6,16,19,37}$

The analysis of the adjusted odds ratio showed that the risk of developing musculoskeletal symptoms was higher for school children in categories $>10 \%$ to $\leq 15 \%$ and $>15 \%$ and this in the French-speaking subsystem compared to the English-speaking subsystem ( $p<0.001)$. There was no significant difference in gender. This result justifies the governmental measures in the field of school policy that took place in November 2017 in Cameroon, which prescribed a single textbook per subject. The back was the least affected zone in comparison to the shoulders and neck $(p<0.001)$. This result joins the observations of Yamato et al. ${ }^{40}$ who in their review did not find an objective link between the symptoms at the back and the weight of the schoolbag. According to these authors, the appearance of pain in this region is much more perceptive.

In the analysis of other factors determining the occurrence of musculoskeletal disorders, only the means moving to and from school was significantly associated with the risk of developing localized pain in the back, shoulders and neck $(p<0.01)$. School children who moved to school using public car transport were less likely to develop musculoskeletal symptoms.

\section{Recommendations}

Compliance with the Government circular on textbooks that prescribed one schoolbook per subject matter instead of the multiple books by subject as it was previously is recommended.

\section{Limitations}

First, the limited sample size cannot allow a generalization of the results at National level. On the other hand, the results obtained may be different if we take into account rural regions where access to the textbook is limited. Second, there is also the cross-sectional nature of the study which does not allow reliable conclusions on the causal link. Third, only few risk factors for musculoskeletal pain were studied. Future studies should highlight the long-term effects of schoolbag weight on musculoskeletal pain and many other risk factors should be investigated.

\section{Conclusions}

The schoolbag weight is high in the Cameroonian education system compared to international standards and is associated with common musculoskeletal pain. Carrying heavy schoolbag is associated to musculoskeletal pain in school children. The means moving to and from school is a main risk factor of developing musculoskeletal pain. Frenchspeaking school children develop less neck pain than English-speaking school children. 


\section{References}

1. Mwaka ES, Munabi IG, Ochieng J. Musculoskeletal pain and school bag use: a cross-sectional study among Ugandan pupils. BMC Res Notes. 2014 Apr 9;7:222.

2. Cottalorda J, Rahmani A, Diop M, Gautheron V, Ebermeyer E, Belli A. Influence of school bag carrying on gait kinetics. J Pediatr Orthop B. 2003 Nov; 12: 357-364.

3. Chow DH, Kwok ML, Cheng JC, Lao ML, Holmes AD, Au-Yang A, Yao FY, Wong MS. The effect of backpack weight on the standing posture and balance of schoolgirls with adolescent idiopathic scoliosis and normal controls. Gait at posture. 2006 Oct;24:173-181.

4. Chow DHK, Leung KTY, Holmes AD. Changes in spinal curvature and proprioception of schoolboys carrying different weights of backpack. Ergonomics. 2007 Dec;50:2148-2156.

5. Chow DHK, Ou ZY, Wang XG. A Lai Short-term effects of backpack load placement on spine deformation and repositioning error in schoolchildren. Ergonomics. 2010 Jan; 53:56-64

6. Dockrell S, Simms C, Blake C. Schoolbag carriage and schoolbag-related musculoskeletal discomfort among primary school children. Appl Ergon. 2015 Nov; $1: 281-90$

7. Al Shahry FS, Almahmoud HA, Alhujairy RI, Aljohi KK. Effect of school bags on body mechanics among Saudi children. Biosci Biotech Res Comm. 2018 JulySep;11:402-408.

8. Ministère de l'Education Nationale et Ministère de l'Enseignement Supérieur et de la Recherche. Poids des cartables. Circulaire $N^{\circ}$ 2008-002 du 11-01-2008, Bulletin officiel $\mathrm{N}^{\circ} 3$ du 17 janvier 2008.

9. Muhammad Salim Khan S, Sheikh M, Inaam-ul-haq, Mariya A. Back pain and school bag use: A cross-sectional study among school children in Kashmir valley. Int J Current Advanced Res. 2017 July; 06(07):4598-4602

10. Poornajaf A, Omidi L, Khodadadi I, Rahim Nejad N, Rahmani A, Akbarzadeh A, Karchani M. Backpack and related health problems among school students. Payesh. 2016;15(1):79-85.

11. Sahib MA. The effects of schoolbags on the health of students. Karbala J Med. 2016 Jun; 9(1):2301-2315.

12. Brackley HM, Stevenson JM. Are children's backpack weight limits enough? A critical review of the relevant literature. Spine (Phila Pa 1976). 2004 Oct 1;29(19):2184-2190.

13. Iyer MR. An ergonomic study of chronic musculoskeletal pain in school children. Ind J Pediatr. 2001 Oct;10: 937-941.

14. Leboeuf-Yde C, Kyvik KO, Bruun NH. Low back pain and lifestyle. Part II - Obesity. Information from a population based sample of 29,424 twin subjects. Spine (Phila Pa 1976). 1999 Apr 15;24:779-784.

15. Shamsoddini AR, Hollisaz MT, Hafezi R. Backpack weight and musculoskeletal symptoms in secondary school students, Tehran, Iran. Iran J Public Health. 2010;39(4):120-125.

16. Whittfield J, Legg SJ, Hedderley DI. Schoolbag weight and musculoskeletal symptoms in New Zealand secondary schools. Appl Ergon. 2005 Mar;36:193-198.

17. Pau M, Pau M. Postural sway modifications induced by backpack carriage in primary school children: a case study in Italy. Ergonomics. 2010 Jul;53:872-881.

18. Dianat I, Javadivala Z, Allahverdipour H. School bag weight and the occurrence of shoulder, hand/wrist and low back symptoms among Iranian elementary school-children. Health Promot Perspect. 2011 Jul 25;1:76-85.

19. Dianat I, Javadivala Z, Asghari-Jafarabadi M, Asl Hashemi A, Haslegrave CM. The use of schoolbags and musculoskeletal symptoms among primary school children: are the recommended weight limits adequate? Ergonomics. 2013;56:7989.

20. Al-Saleem SA, Ali A, Ali SI, Alshamrani AA, Almulhem AM, Al-Hashem MH. A Study of School Bag Weight and Back Pain among Primary School Children in Al-Ahsa, Saudi Arabia. Epidemiol (Sunnyvale). 2016 Fev;6(1):222.
21. Azabagic S, Spahic R, Pranjic N, Mulic M. Epidemiology of musculoskeletal disorders in primary school children in Bostnia and herzegovina. Mater Sociomed. 2016 Jun;28(3):164-167.

22. Delele M, Janakiraman B, Bekele Abebe A, Tafese A, van de Water ATM. Musculoskeletal pain and associated factors among Ethiopian elementary school Children. BMC Musculoskelet Disord. 2018 Jul 31;19(1):276.

23. Smith DR, Leggat PA. Back Pain in the Young: A Review of Studies Conducted Among School Children and University Students. Curr Pediatr Rev. 2007;3(1):69-

24. Dockrell S, Kane C, O'keefe E. Schoolbag weight and the effects of schoolbag carriage on secondary school students. Meeting Diversity Ergon. 2006;9:216-222.

25. Ugur C, Ali, Beyza C. Non-specific low back pain in a Turkish population based sample of school children: a field survey with analysis of associated factors. The Pain Clinic 2006 0ct;18(4):351-360.

26. Troussier B, Davoine P, de Gaudemaris R, Fauconnier J, Phelip X. Back pain in school children: a study among 1178 pupils. Scand | Rehabil Med. 1994 Sep;26:143-146.

27. Spiteri K, Busuttil M, Aquilina S, Gauci D, Camilleri E, Grech V. Schoolbags and back pain in children between 8 and 13 years: a national study. Br J Pain. 2017 May; 11:81-86.

28. Wirth B, Humphreys BK. Pain characteristics of adolescent spinal pain. BMC Pediatr. 2015 Apr 17:15(1):42.

29. Siambanes D, Martinez JW, Butler EW, Haider T. Influence of school backpacks on adolescent back pain. J Pediatr Orthop. 2004 Mar-Apr;24(2):211-217.

30. Negrini S, Carabalona R, Sibilla P. Backpack as a daily load for school-children. Lancet. 1999 Dec 4;354(9194):1974.

31. Ibrahim AH. Incidence of Back Pain in Egyptian School Girls: Effect of school Bag Weight and Carrying Way. World Appl Sci J. 2012;17:1526-1534.

32. Giusti PH, De Almeida Jr. HL, Tomasi E. Weight excess of school materials and its risks factors in South Brazil. A cross sectional study. Eur J Phys Rehabil Med. $2008 \mathrm{Mar} ; 44(1): 33-38$.

33. Al-Hazzaa HM. School backpack. How much load do Saudi school boys carry on their shoulders? Saudi Med J. 2006 0ct; 27(10):1567-1571.

34. Read T. Where Have All the Textbooks Gone? The Affordable and Sustainable Provision of Learning and Teaching Materials in Sub-Saharan Africa. Washington, DC: World Bank Group. 2015 Jul. https://doi.org/10.1596/978-1-4648-0572-1.

35. Daneshmandi H, Rahmani-Nia F, Hosseini SH. Effect of carrying school backpacks on cardio-respiratory changes in adolescent students, Sport Sci Health. 2008 Dec;4:7-14

36. Furjuoh SN, Schuchmann JA, Lane BL. Correlates of heavy backpack use by elementary school children. Public health. 2004 0ct;118(7):532-535

37. Dorji T, Tamang ST, Yoezer S, Wangdi K. The Weight of Schoolbags and Musculoskeletal Pain in Children of Selected Schools in Thimphu, Bhutan: A Cross-sectional Study. Int J Med Students. 2019 May-Aug;7(2):29-32.

38. Usman G, Agha S, Ameen F. Effect of heavy bags, plus desks and postura variations association with lower back pain in school going children. Gonal Univ J Res. 2014 Jun;30(1):76-83.

39. Grimmer K, Dansie B, Milanese S, Pirunsan U, Trott P. Adolescent standing postural response to backpack loads: a randomized controlled experimental study. BMC Musculoskelet Disord. 2002 Apr 17; 3:10.

40. Yamato TP, Maher CG, Traeger AC, Williams CM, Kamper SJ. Do schoolbags cause back pain in children and adolescents? A systematic review. $\mathrm{Br} J$ Sports Med. 2018 0ct;52(19):1241-1245. 


\section{Original Article}

\section{Acknowledgments}

We thank the principals, teachers and parents of children for their collaboration. We also thank the students who participated and, Loick Pradel Kojom for its advices in statistical analysis.

\section{Conflict of Interest Statement t Funding}

The Authors have no funding, financial relationships or conflicts of interest to disclose.

\section{Author Contributions}

Conceptualization: WRG a PBAN. Data Curation, Methodology, Resources a Validation: WRG, PBAN, EEM, JMN, CBBL, WMB, ELDS, JBO \& AT. Formal Analysis, Project Administration, ¿t Supervision: WRG, PBAN, SHM थ AT. Investigation: WRG, PBAN, ELDS \& JBO. Visualization: WRG, PBAN थ CBBL. Writing - Original Draft Preparation: WRG, PBAN, EEM, SHM ¿t AT. Writing - Review at Editing: WRG, PBAN, SHM đa AT.

Cite as:

Guessogo WR, Assomo-Ndemba PB, Ebal-Minye E, Mekoulou-Ndongo J, Bika-Lélé CB, Mbang-Bian W, et al. Effect of Schoolbag Weight on Musculoskeletal Pain among Primary School Children in Yaounde, Cameroon: A Cross-sectional Study. Int J Med Students. 2020 May-Aug;8(2):96-101.

This work is licensed under a Creative Commons Attribution 4.0 International License 